\title{
A myocardialis necrosis mértékének vizsgálata eltérő supraventricularis szívritmuszavarok rádiófrekvenciás katéterablatiós kezelését követően
}

\author{
Tahin Tamás dr. ${ }^{1 *}$ - Herczeg Szilvia dr. ${ }^{1 *}$ - Gellér László dr. ${ }^{1}$ \\ Boros András Mihály dr. ${ }^{1}$. Kovács Orsolya Mária dr. ${ }^{1}$ \\ Szegedi Nándor dr. ${ }^{1}$ - Fórizs Éva ${ }^{1}$ - Szilágyi Szabolcs dr. ${ }^{1}$ \\ Osztheimer István dr. ${ }^{1}$ - Merkely Béla dr. ${ }^{1 * *}$. Széplaki Gábor dr. ${ }^{1,2 * *}$ \\ ${ }^{1}$ Semmelweis Egyetem, Általános Orvostudományi Kar, Városmajori Szív- és Érgyógyászati Klinika, Budapest \\ ${ }^{2}$ Heart and Vascular Centre, Mater Private Hospital, Dublin, Írország
}

\begin{abstract}
Bevezetés: Ismert, hogy katéteres ablatio által okozott szívizom-károsodás következtében megnő a szívizom-specifikus nekroenzimek koncentrációja.

Célkitüzés: A magas érzékenységü troponin T (hsTnT) és a szívizom-specifikus kreatin-kináz (CKMB) szintje középtávú változásának elemzése pitvarfibrilláció $(\mathrm{PF})$, pitvari flutter (PFlu), AV-csomó reentry tachycardia (AVNRT) rádiófrekvenciás katéteres ablatióját követően, illetve elektrofiziológiai vizsgálat után.

Módszer: Rádiófrekvenciás ablatión, illetve elektrofiziológiai vizsgálaton átesett betegeket vontunk be konszekutívan prospektív vizsgálatunkba. Sorozatvérmintákból meghatároztuk a hsTnT- és a CKMB-szinteket a procedúra előtt és után közvetlenül, majd 4 és 20 órával és 3 hónappal később.

Eredmények: Negyvenhét, $55 \pm 13$ év átlagéletkorú beteget (10 elektrofiziológiai vizsgálat, 12 AVNRT, 13 PFlu és $12 \mathrm{PF}$ ) vontunk be vizsgálatunkba. A hsTnT-szintek minden csoportban szignifikánsan megemelkedtek a beavatkozást követôen, a CKMB csak a PF-csoportban változott. A hsTnT-szint négy órával a beavatkozást követően az összes ablatión átesett betegnél és az elektrofiziológiai vizsgálaton átesett betegek $80 \%$-ánál meghaladta a referenciatartományt. A legmagasabb átlagos hsTnT-koncentrációk EFV, AVNRT, PFlu esetén $24 \pm 11,260 \pm 218$ és $541 \pm 233$ ng/l-nek bizonyultak. A legmagasabb hsTnT-szint a PF-ablatiós csoportban volt kimutatható 20 órával az ablatio után $(799 \pm 433 \mathrm{ng} / \mathrm{l})$. Pozitív korrelációt találtunk a rádiófrekvenciás ablatiót követő hsTnT-szint és az ablatio ideje között.

Következtetések: A hsTnT alkalmas a rádiófrekvenciás ablatio és az elektrofiziológiai vizsgálat utáni myocardialis necrosis vizsgálatára, az ablatión átesett betegek mindegyikénél; elektrofiziológiai vizsgálat után $80 \%$-ban pozitív a hsTnT. A necrosis mértéke jelentôsen függ a beavatkozás típusától, és korrelál az ablatio kiterjedtségével. A fentiekben leírt megfigyelések iránymutatásként szolgálnak a rádiófrekvenciás ablatio utáni hsTnT-szint megfelelő értelmezéséhez.
\end{abstract}

Orv Hetil. 2019; 160(14): 540-548.

Kulcsszavak: katéteres ablatio, aritmia/fiziopatológia, pitvarfibrilláció, biomarkerek/vér, troponin

\section{Assessment of the extent of myocardial necrosis following radiofrequency catheter ablation of different supraventricular arrhythmias}

Introduction: Levels of cardiac necroenzymes, high-sensitive troponin (hsTnT) and creatine kinase muscle-brain $(\mathrm{CKMB})$ increase as a result of a myocardial damage following catheter ablation.

Aim: To analyze the mid-term alteration of hsTnT and CKMB levels following radiofrequency ablation (RFCA) for atrial fibrillation (AF), atrial flutter (AFlu), AV-nodal reentry tachycardia (AVNRT) and electrophysiological studies (EPS) without ablation. 
Method: Patients undergoing RFCA for various indications and EPS were consecutively enrolled in our prospective study. Concentrations of hsTnT and CKMB were measured from serial blood samples directly before and after the procedure, 4 and 20 hours later and at 3 months follow-up.

Results: Forty-seven patients (10 EPS, 12 AVNRT, 13 AFlu, 12 AF) with mean age of $55 \pm 13$ were included. hsTnT levels increased significantly in all groups after the procedures, while CKMB changed only in the AF group. hsTnT exceeded the reference value in all patients with ablation and in $80 \%$ of patients with EPS 4 hours post-ablation. Peak average hsTnT levels for EPS, AVNRT, AFlu were $24 \pm 11,260 \pm 218$ and $541 \pm 233 \mathrm{ng} / \mathrm{L}$, respectively. The highest hsTnT level was measured in the $\operatorname{AF}$ group $(799 \pm 433 \mathrm{ng} / \mathrm{L})$. We found a positive correlation between hsTnT levels and ablation time after RFCA.

Conclusions: The hsTnT levels significantly change after EPS and RFCA, in all patients who underwent ablation, and in $80 \%$ of those with EPS had hsTnT positivity in the early post-procedural phase. hsTnT levels depended significantly on the type of the subgroups and correlated with the ablation time. Awareness of those observations is essential to correctly interpret elevated hsTnT levels following RFCA.

Keywords: catheter ablation, arrhythmias, cardiac/physiopathology, atrial fibrillation, biomarkers/blood, troponin

Tahin T, Herczeg Sz, Gellér L, Boros AM, Kovács OM, Szegedi N, Fórizs É, Szilágyi Sz, Osztheimer I, Merkely B, Széplaki G. [Assessment of the extent of myocardial necrosis following radiofrequency catheter ablation of different supraventricular arrhythmias]. Orv Hetil. 2019; 160(14): 540-548.

(Beérkezett: 2018. október 17.; elfogadva: 2018. november 14.)

\section{Rövidítések}

ACT $=$ (activated clotting time) aktivált alvadási idő; ANOVA $=($ analysis of variance $)$ egyirányú varianciaanalízis; $\mathrm{AV}=$ atrioventricularis; AVNRT $=$ (atrioventricular nodal reentry tachycardia) $\mathrm{AV}$-csomó reentry tachycardia; $\mathrm{CKMB}=($ creatine kinase muscle-brain) szívizom-specifikus kreatin-kináz; CT = (computed tomography) számítógépes tomográfia; $\mathrm{CTI}=\mathrm{ca}$ votricuspidalis isthmus; $\mathrm{CV}=$ cardioversio $; \mathrm{EDTA}=($ ethylenediaminetetraacetic acid) etilén-diamin-tetraecetsav; $\mathrm{EFV}=$ elektrofiziológiai vizsgálat; EKG = elektrokardiográfia; ESC = (European Society of Cardiology) Európai Kardiológus Társaság; hsTnT = (high-sensitive troponin $\mathrm{T}$ ) magas érzékenységú troponin T; ICD = (implantable cardioverter-defibrillator) beültethető kardioverter-defibrillátor; $\mathrm{PF}=$ pitvarfibrilláció; PFlu = típusos pitvari flutter; $\mathrm{PV}=$ pulmonalis véna; $\mathrm{PVI}=$ pulmonalisvéna-izoláció; $\mathrm{RF}=$ rádiófrekvenciás; $\mathrm{WPW}=$ Wolf-Parkinson-White-szindróma

A szívritmuszavarok definitív kezelésében jelentôs szerepe van a katéterablatiónak, mely látványos fejlődésen ment keresztül az utóbbi két évtizedben. A módszer során a ritmuszavar kialakulásáért felelős aritmiaszubsztrát kerül előbb azonosításra, majd azt követően az ablatiós katéter által leadott energia segítségével roncsolásra, mely a ritmuszavar megszúnéséhez vezet, és meggátolja annak későbbi előfordulását [1-3]. Az adott ritmuszavarra jellemző szubsztrát meghatározza az ablatio pontos helyét és a roncsolni kívánt terület mértékét, mely igen eltérő a különböző supraventricularis és ventricularis ritmuszavarok esetén [4]. A klinikai gyakorlatban az ablatio kivitelezésére dominálóan használatos energiaforrás a rádiófrekvencia általi hőközlés, azonban más energiaforrások is ismeretesek [5].
Az elmúlt évtizedben világszerte rutinszerúen elterjedt a szívizomnecrosis mértékének megállapítására a magas szenzitivitású troponin $\mathrm{T}$ (hsTnT) [6]. Habár a leggyakrabban az akut coronariaszindróma diagnosztikája során alkalmazzák, a szívizomnecrosis mértékének gyors és specifikus kimutatásával egyéb szívbetegségekben is prognosztikus jelentőséggel bírhat $[7,8]$. Ráadásul a mindennapi klinikai gyakorlatban ma már könnyen elérhető és alkalmazható bármelyik centrumban. Továbbá a tradicionális troponinszintmérésekhez képest a hsTnT használatával precízebben, akár tízszer alacsonyabb koncentrációt is lehetséges kimutatni [8].

Rádiófrekvenciás (RF) ablatio során lokalizált szöveti necrosis jön létre a szívben, ami a szisztémás myocardialis necrosis biomarkerek kiáramlásához, így azok szintjének emelkedéséhez vezet [9]. Annak ellenére, hogy ez a jelenség jól ismert, az irodalomban kevés adat áll rendelkezésre arról, hogy ennek mértéke hogyan függ össze a beavatkozás típusával, amelyet az aritmiamechanizmus határoz meg [10]. Ezenfelül a rendelkezésre álló publikációk nagy részében a necrosis mértékének jellemzésére nem használták a hsTnT-meghatározást [7]. A vizsgálatok rövid utánkövetési ideje is korlátozza a szívizom-károsodás változásának teljes körú megfigyelését [11, 12]. Jelen tanulmányunkban azt tûztük ki célul, hogy több különböző típusú supraventricularis ritmuszavar esetén alkalmazott RF ablatiós kezelés után a hsTnT és a szívizom-specifikus kreatin-kináz (CKMB) meghatározásának segítségével jellemezzük a myocardialis necrosis mértékét és annak összefüggését az ablatio mértékével, továbbá elemezzük a következményes klinikai relevanciát. 


\section{Módszer}

\section{Betegek és vizsgálati felépités}

Az egycentrumos, prospektív, obszervációs vizsgálatba a Semmelweis Egyetem Városmajori Szív- és Érgyógyászati Klinikájának Elektrofiziológiai Laboratóriumában különböző supraventricularis ritmuszavarok miatt rádiófrekvenciás (RF) ablatiós kezelésre előjegyzett betegeket vontunk be konszekutívan. Kizárási kritériumnak a kiindulási mintában abnormálisan magas myocardialis nekroenzimszinteket tekintettük (ez a laboratóriumi referenciatartományt meghaladó, >14 ng/l értéket jelentette). A vizsgálatba 51 beteget vontunk be, akik közül 12 beteg pitvarfibrilláció (PF), 13 beteg típusos pitvari flutter (PFlu) és 13 beteg $\mathrm{AV}$-csomó reentry tachycardia (AVNRT) miatt esett át kezelésen. A vizsgálatba kontrollcsoportként 13 olyan beteget választottunk be, akiknél invazív szívelektrofiziológiai vizsgálat (EFV) történt, azonban RF ablatiós kezelés nem. A betegeknél sorozat-vérmintavételeket és laboratóriumi vizsgálatot végeztünk közvetlenül a beavatkozás elött (kiindulás) és után (0. óra), majd 4 órával, 20 órával és 3 hónappal a beavatkozás után. A vérmintákból a hsTnT és a CKMB szintjét határoztuk meg, és ezekből következtettünk a szívizomnecrosis mértékére. A fenti kizárási kritériumnak megfelelően négy beteget - mivel háromnál az EFVcsoportban és egynél az AVNRT-csoportban magasan kiugró kezdeti hsTnT-értéket mértünk - kizártunk a vizsgálatból, így a továbbiakban 47 beteg nekroenzimértékét vizsgáltuk. A vizsgálati protokoll megfelelt a helsinki nyilatkozatban foglaltaknak, azt a helyi etikai bizottság engedélyezte, és felvilágosítást követően a betegek mindegyike hozzájárult a vizsgálatban való részvételhez.

\section{Invazív EFV és RF ablatiós kezelés}

Az EFV és a RF [13] ablatiós kezelés indikációi és az alkalmazott technikák megfeleltek az Európai Kardiológus Társaság (ESC) aktuális irányelveiben foglaltaknak [13$15]$.

Tünetekkel rendelkező PF miatt pulmonalisvéna-izoláción (PVI) 12 beteg esett át, ezeknél a betegeknél vagy hatástalan volt legalább egy antiaritmikum, vagy strukturális szívbetegséggel nem rendelkeztek, és első vonalbeli terápiaként választották az invazív kezelést. PVI előtt minden betegnél bal pitvari CT-angiográfia és transoesophagealis ultrahangvizsgálat történt az anatómia pontos megismerésére és a bal pitvari fülcsethrombus kizárása céljából. A beavatkozásokat éber szedáció mellett, intravénás propofol, midazolám és fentanil alkalmazásával végeztük. Katétereket vezettünk fel a jobb pitvarba a jobb combvéna punkcióján keresztül, majd fluoroszkópés nyomásvezérelt transseptalis szúrással átjuttattuk a katétereket a bal pitvarba. Ezután egy körkörös térképező-, diagnosztikus katétert (Lasso, Biosense Webster, Inc., Irvine, CA, Egyesült Államok [USA]), illetve egy 3,5 mm végú irrigált ablatiós katétert (ThermoCool, Dcurve, Biosense Webster, Inc.) vezettünk fel a bal pitvarba. A beavatkozás során a tájékozódást háromdimenziós elektroanatómiai térképezőrendszer segítette, mely a korábbi bal pitvari CT-kép egyesítésével készített háromdimenziós rekonstrukciós képet a bal pitvarról. A pulmonalis vénákat két széles antralis, körkörös ablatiós vonallal izoláltuk elektromosan a pitvartól. Az ablatio során RF energiát használtunk $43{ }^{\circ} \mathrm{C}$-os hőmérsékleti és 30 $\mathrm{W}$-os energialimittel. A beavatkozás alatt intravénás $\mathrm{Na}$ heparint alkalmaztunk a megfelelő, 250-350 másodperces aktivált alvadási idő (ACT) elérésére. Amennyiben a beteg az összes pulmonalis véna (PV) izolálása után is pitvarfibrillált, EKG-szinkrón elektromos cardioversiót alkalmaztunk. Akutan sikeresnek tekintettük a beavatkozást, amennyiben kétirányú blokkot igazoltunk az összes PV esetén, mely 20 perces várakozás után is fennállt.

A vizsgálatban tizenhárom, dokumentált, típusos pitvari flutterben szenvedő beteg esetében került sor ablatiós kezelésre, melynek során a cavotricuspidalis isthmuson (CTI) alkalmaztunk RF applikációkat. A beavatkozást éber szedáció mellett intravénás propofol, midazolám és fentanil alkalmazásával végeztük. A jobb combvénán keresztül egy húszpólusú diagnosztikus katétert (ViaCath, Biotronik, Berlin, Németország) és egy $4 \mathrm{~mm}$ végú irrigált ablatiós katétert (AlCath Flux Black Gold, Biotronik) vezettünk fel a jobb pitvarba fluoroszkóp segítségével. A CTI-n pontról pontra történó RF ablatiót $43^{\circ} \mathrm{C}$-os hőmérsékleti és $40 \mathrm{~W}$-os energialimittel végeztük. Sikeresnek tekintettük a beavatkozást, ha a CTI-n kétirányú blokkot verifikáltunk az utolsó applikáció után 20 perc elteltével is, sinusrhythmus mellett.

Tizenkét pácienst paroxismalis supraventricularis tachycardia gyanúja miatt vizsgáltunk. Amennyiben a következő bekezdésben részletezett $\mathrm{EFV}$ során kettős AV-csomó-vezetést igazoltunk, és emellett a betegnél kiváltható volt egy AV-csomó reentryn alapuló supraventricularis tachycardia, vagy rendelkezett dokumentált keskeny QRS reguláris tachycardiával, AVNRT-t diagnosztizáltunk. Ezután nem irrigált ablatiós katétert (AlCath Blue, Biotronik) vezettünk be a combvénán keresztül a jobb pitvarba, és RF applikáció leadásával megszüntettük a lassú pálya elektromos vezetőképességét. Az ablatiók során $65^{\circ} \mathrm{C}$-os hőmérsékleti és $40 \mathrm{~W}$-os energialimitet használtunk a nem hưtött fejű ablatiós katéteren keresztül. A beavatkozást sikeresnek véltük, amenynyiben az EFV megismétlésével az ablatio utáni 20 perc elteltével sem találtunk kettős AV-csomó-vezetést.

További tíz esetben EFV-t végeztünk, melynek során a szív ingervezetô rendszerét jellemeztük, illetve megvizsgáltuk, hogy kiváltható-e olyan ritmuszavar, amely megfelel a betegek tüneteinek (szívdobogásérzés, syncope). A beavatkozás során a páciensek a jobb lágyéktáj lokális érzéstelenítése mellett szedatívum alkalmazását nem igényeltek. A beavatkozás alatt három katétert vezettünk fel a jobb combvénán keresztül: egyet a magas jobb pitvari (késóbb áthelyezve a His-) pozícióba, egyet 
a sinus coronariusba, a harmadikat pedig a jobb kamrai csúcsba. Az esetleges ritmuszavarok kiváltását fokozatosan csökkenő ciklushosszú jobb pitvari ingerlés mellett kíséreltük meg, illetve decrementalisan leadott extra ütések alkalmazásával a refrakteritás eléréséig. Amennyiben nem volt kiváltható ritmuszavar, megismételtük a pitvari extrastimulációt intravénás izoproterenol hatása alatt is. Ezután kamrai extrastimuláció alkalmazásával határoztuk meg a refrakteritás szintjét, és vizsgáltuk a kamrai ritmuszavarok kiválthatóságát. A vizsgált tíz esetben nem tudtunk supraventricularis ritmuszavart kiváltani. Egy esetben kamrai tachycardiát indukáltunk, melyet antitachycardiaingerléssel termináltunk, egy esetben pedig kamrafibrilláció indult, melyet defibrillációval termináltunk. Az EFV-esetek során ablatiót nem végeztünk, így kontrollcsoportként szolgáltak vizsgálatunkban.

\section{Vérvétel és laborvizsgálatok}

A betegektől éhomi vérmintát nyertünk standard eljárással az antecubitalis régióból a beavatkozás előtt közvetlenül, illetve az EFV vagy RF ablatio utáni 0. órában. Ezt megismételtük a beavatkozást követő 4 . és 20 . órában is. Az utolsó vérmintát a 3 . hónapos kontrollvizsgálat során nyertük. A vérmintát EDTA-val antikoagulált csövekbe gyưjtöttük, majd a mintavételtól számítva egy órán belül centrifugálással különválasztottuk a plazmát. Ezután több aliquotba osztva rögtön $-80^{\circ} \mathrm{C}$-ra fagyasztottuk, hogy a biomarkerek szignifikáns koncentrációváltozását megakadályozzuk. Az összegyújtött fagyasztott mintákból meghatároztuk a myocardialis necrosis markereinek (hsTnT, CKMB) szintjét abszorbciós fotometrikus és turbidimetriás technikával a Cobas Integra 400 plus ${ }^{\circledR}$ (Mannheim, Németország) klinikai kémiai rendszer segítségével.

\section{Statisztikai analizis}

A vizsgálatba bevont betegek kórtörténetét, a beavatkozások jellemzőit és a mért myocardialis necrosis markerek mértékét vetettük össze. Mivel alacsony esetszámokkal dolgoztunk, a Shapiro-Wilk-normalitásteszt alapján nem gaussi eloszlású változók esetében is parametrikus tesztet alkalmazhattunk. A folytonos változók átlag \pm standard deviáció megadásával, míg a kategorikus változók esetszámmal és százalékos megoszlással vannak feltüntetve, amennyiben ez másként nem került megjelölésre. Az egymástól független folytonos változókat nem

1. táblázat |A vizsgált populáció demográfiai és klinikai jellemzői

\begin{tabular}{|c|c|c|c|c|c|}
\hline & $\begin{array}{l}\text { EFV } \\
(\mathrm{n}=10)\end{array}$ & $\begin{array}{l}\text { AVNRT } \\
(\mathrm{n}=12)\end{array}$ & $\begin{array}{l}\text { PFlu } \\
(\mathrm{n}=13)\end{array}$ & $\begin{array}{l}P F \\
(n=12)\end{array}$ & $\begin{array}{l}\text { Összes beavatkozás } \\
(\mathrm{n}=47)\end{array}$ \\
\hline Életkor & $51( \pm 16)$ & $46( \pm 12)$ & $62( \pm 11)$ & $59( \pm 8)$ & $55( \pm 13)$ \\
\hline Női nem & $5(50 \%)$ & $8(67 \%)$ & $3(23 \%)$ & $3(25 \%)$ & $18(38 \%)$ \\
\hline BMI & $30( \pm 5)$ & $27( \pm 4)$ & $27( \pm 3)$ & $28( \pm 3)$ & $28( \pm 4)$ \\
\hline Krónikus szívelégtelenség & $1(10 \%)$ & 0 & $1(8 \%)$ & 0 & $2(4 \%)$ \\
\hline Hypertonia & $7(70 \%)$ & $4(33 \%)$ & $8(62 \%)$ & $7(58 \%)$ & $26(55 \%)$ \\
\hline Diabetes mellitus & $1(10 \%)$ & 0 & $3(23 \%)$ & $1(8 \%)$ & $5(11 \%)$ \\
\hline Előző stroke/TIA & $1(10 \%)$ & 0 & $2(15 \%)$ & 0 & $3(6 \%)$ \\
\hline Előző myocardialis infarctus & $3(30 \%)$ & 0 & $2(15 \%)$ & 0 & $5(11 \%)$ \\
\hline PCI által revaszkularizált & $2(20 \%)$ & 0 & $2(15 \%)$ & 0 & $4(9 \%)$ \\
\hline CABG által revaszkularizált & $2(20 \%)$ & 0 & $1(8 \%)$ & 0 & $3(6 \%)$ \\
\hline Obliterativ érbetegség & 0 & 0 & 0 & 0 & 0 \\
\hline Tüdőembólia & 0 & 0 & $1(8 \%)$ & 0 & $1(2 \%)$ \\
\hline Mélyvénás trombózis & 0 & $1(8 \%)$ & 0 & 0 & $1(2 \%)$ \\
\hline COPD & 0 & 0 & $1(8 \%)$ & 0 & $1(2 \%)$ \\
\hline Zsíranyagcsere-zavar & $5(50 \%)$ & $1(8 \%)$ & $1(8 \%)$ & $1(8 \%)$ & $8(17 \%)$ \\
\hline Hangulatzavar & $1(10 \%)$ & 0 & 0 & $1(8 \%)$ & $2(4 \%)$ \\
\hline Korábban beültetett PM/ICD & $1(10 \%)$ & 0 & $2(15 \%)$ & $1(8 \%)$ & $4(9 \%)$ \\
\hline Ejekciós frakció (\%) & $58( \pm 11)$ & $66( \pm 7)$ & $58( \pm 12)$ & $57( \pm 12)$ & $59( \pm 11)$ \\
\hline Procedúraidő (perc) & $26( \pm 10)$ & $46( \pm 16)$ & $57( \pm 26)$ & $73( \pm 15)$ & $52( \pm 24)$ \\
\hline Ablatiós idő (perc) & 0 & $2( \pm 1)$ & $19( \pm 14)$ & $17( \pm 12)$ & $10( \pm 13)$ \\
\hline Sugáridő (perc) & $2( \pm 1)$ & $7( \pm 5)$ & $12( \pm 9)$ & $22( \pm 9)$ & $11( \pm 10)$ \\
\hline
\end{tabular}

AVNRT = AV-csomó reentry tachycardia; BMI = testtömegindex; CABG = coronaria bypass graft; COPD = krónikus obstruktív tüdőbetegség; $\mathrm{EFV}$ = elektrofiziológiai vizsgálat; $\mathrm{ICD}=$ beültethető kardioverter-defibrillátor; $\mathrm{PCI}=$ perkután coronariaintervenció; PF = pitvarfibrilláció; PFlu = pitvari flutter; $\mathrm{PM}=$ pacemaker; TIA = tranziens ischaemiás attak 
párosított t-teszttel hasonlítottuk össze. Több összefüggő folyamatos változó összehasonlításához egyirányú varianciaanalízist alkalmaztunk (ANOVA) GreenhouseGeisser-korrekcióval, illetve az alcsoportok összehasonlítására a Tukey-féle post-hoc tesztet használtuk. Két folytonos változó közötti korreláció feltárására a Pearson-korrelációt alkalmaztuk. A statisztikai analízisek esetében a kétoldalú $\mathrm{p}<0,05$ értéket tekintettük szignifikánsnak, kivitelezéshez a Prism szoftver 6.01 verzióját (GraphPad Software, Inc., La Jolla, CA, USA) használtuk.

\section{Eredmények}

\section{Vizsgálati populáció és beavatkozási adatok}

A vizsgált betegpopuláció és kontrollcsoport klinikailag releváns jellemzőit, a beavatkozás adatait az 1 . táblázat részletezi. A 47 beteg életkora átlagosan $55 \pm 13$ év, kisebb arányban nók (38\%), testtömegindexük alapján átlagosan túlsúlyosak. A vizsgált egyének között gyakori volt a magasvérnyomás-megbetegedés (55\%), a zsíranyagcsere-zavar (17\%), a 2-es típusú cukorbetegség (11\%) és a korábbi szívinfarktus (11\%). Négy esetben korábban beültetett pacemaker vagy kardioverter-defibrillátor (ICD) mellett végeztük a beavatkozást. A betegek átlagosan jó szisztolés balkamra-funkcióval rendelkeztek $(59 \pm 11 \%)$.

Az ablatiót a beavatkozás végén minden esetben sikeresnek ítéltük mindhárom alcsoportban (AVNRT, PFlu, PF). A különböző aritmiaszubsztrátok jellegéből adódóan az ablatiót is és a várakozási időt is magában foglaló procedurális idő az AVNRT-, a PFlu- és a PF-csoportban magasabb volt a kontrollként szereplő EFV-csoporthoz képest - átlagosan $46 \pm 16,57 \pm 26$, illetve $73 \pm 15$ perc -, és jelentősen különbözött az ablatiós idő is. A beavatkozásokhoz átlagosan $11 \pm 10$ percig tartó röntgenátvilágítás érte a betegeket, mely EFV és AVNRT alatt átlagosan $2 \pm 1$, illetve $7 \pm 5$ perc, míg PFlu- és PF-ablatio alatt $12 \pm 9$, illetve $22 \pm 9$ perc volt (1. táblázat).

\section{A myocardialis necrosis markerek változása ablatiót köpetöen}

A myocardialis biomarkerek kiindulási értékeit a különböző csoportokban a 2. táblázat mutatja be. Összehasonlítva az értékeket, egyedül a PFlu- és az AVNRT-csoportban találtunk kezdeti szignifikáns $(\mathrm{p}=0,0382)$, de klinikailag nem releváns különbséget.

A sorozat-mintavételeket követően meghatároztuk a myocardialis biomarkerek szintjeit, melynek változását a különböző csoportokban az 1 . ábra mutatja be. A CKMB-szintváltozást vizsgálva a varianciaanalízis alapján egyedül a PF-csoport mutatott szignifikáns változást $(\mathrm{p}=0,0210)$, azonban többszörös időpontokat összeve-
2. táblázat | Biomarkerek kiindulási szintjei beavatkozás előtt a különböző betegcsoportokban

\begin{tabular}{lcccc}
\hline Biomarker & $\begin{array}{c}\text { EFV } \\
(\mathrm{n}=10)\end{array}$ & $\begin{array}{c}\text { AVNRT } \\
(\mathrm{n}=12)\end{array}$ & $\begin{array}{c}\text { Pflu } \\
(\mathrm{n}=13)\end{array}$ & $\begin{array}{c}\text { PF } \\
(\mathrm{n}=12)\end{array}$ \\
\hline CKMB & $12( \pm 3)$ & $17( \pm 17)$ & $16( \pm 9)$ & $14( \pm 2)$ \\
hsTnT & $8( \pm 5)$ & $5( \pm 4)$ & $9( \pm 5)$ & $7( \pm 4)$ \\
\hline
\end{tabular}

AVNRT $=$ AV-csomó reentry tachycardia CKMB = szívizom-specifikus kreatin-kináz; EFV = elektrofizológiai vizsgálat; hsTnT = magas érzékenységű troponin T; $\mathrm{PF}=$ pitvarfibrilláció; PFlu = pitvari flutter
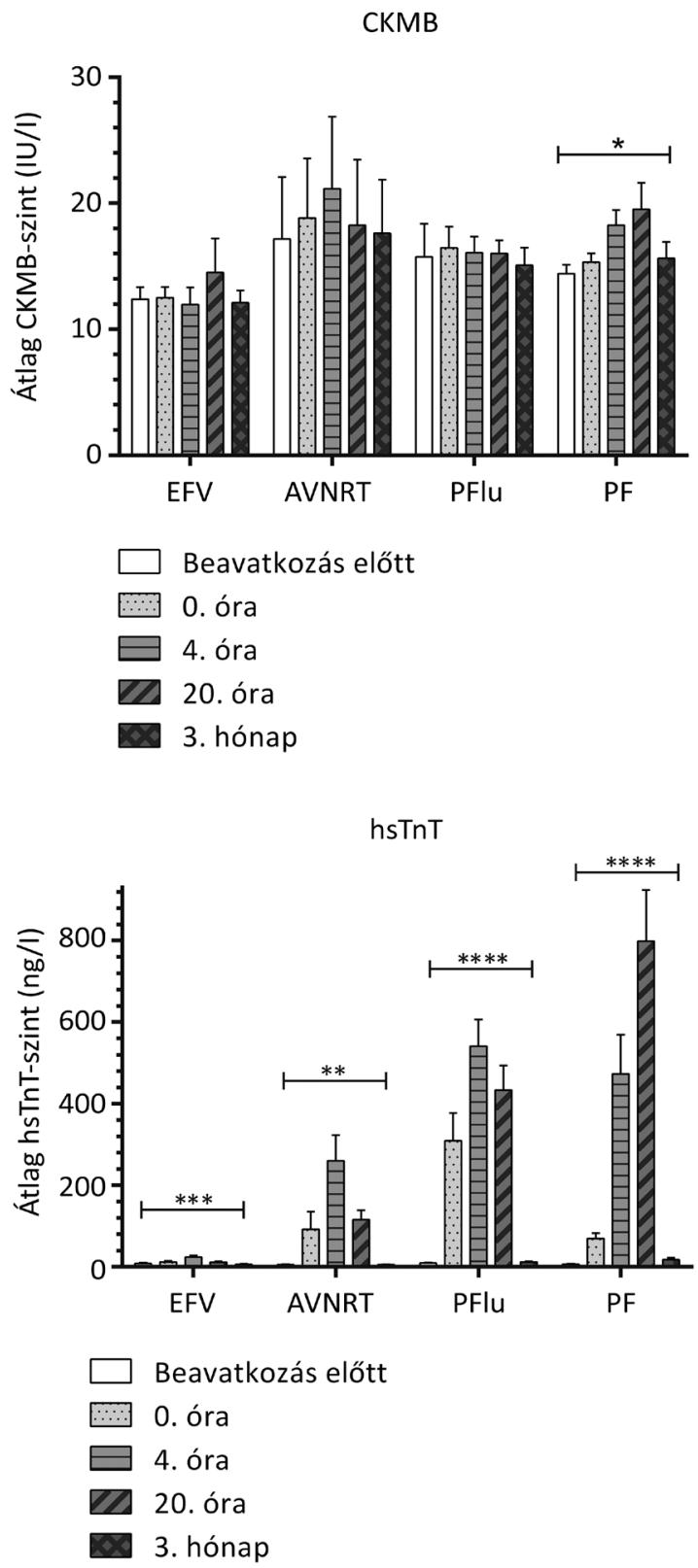

1. ábra A CKMB és a hsTnT változása a beavatkozás típusa szerint AVNRT $=$ AV-csomó reentry tachycardia; $\mathrm{CKMB}=$ szívizomspecifikus kreatin-kináz; EFV = elektrofiziológiai vizsgálat; PF = pitvarfibrilláció; PFlu $=$ pitvari flutter

Csoportonként egyirányú varianciaanalízis (ANOVA) szignifikanciaszintjei: ${ }^{*} \mathrm{p}<0,05,{ }^{* *} \mathrm{p}<0,01,{ }^{* * *} \mathrm{p}<0,001,{ }^{* * * *} \mathrm{p}<0,0001$ 
tő alcsoport-összehasonlítás esetén nem volt szignifikáns a különbség.

A hsTnT-t tekintve minden csoportban észlelhető volt szignifikáns változás. EFV után a hsTnT szintje a 4. órára megemelkedett átlagosan $24 \pm 11 \mathrm{ng} / \mathrm{l}$ mértékig, azonban a 3. hónapos kontrollvizsgálatra ez az érték normalizálódott ( $\mathrm{p}=0,0002$ a varianciaanalízisre). A troponinemelkedés AVNRT- és PFlu-ablatio esetén is a 4. órában érte el a maximumát, átlagosan $260 \pm 218$ ng/l, illetve $541 \pm 233 \mathrm{ng} / \mathrm{l}$ volt. A hsTnT értéke mindkét csoportban szignifikánsan lecsökkent a 3 . hónapra, átlag $5 \pm 3 \mathrm{ng} / \mathrm{l}$, illetve $12 \pm 7 \mathrm{ng} / \mathrm{l}$ értékre $(\mathrm{p}=0,0016$, illetve $\mathrm{p}<0,0001)$. PF esetén figyeltük meg a legmagasabb átlagértéket, itt a beavatkozás előtti átlagos $7 \pm 4$ ng/l szinthez képest a 20. órás csúcskoncentráció átlagosan $799 \pm 433 \mathrm{ng} / \mathrm{l}$ volt. A 3. hónapos kontrollvizsgálaton az ablatio utáni 4., illetve 20 . órához képest markáns csökkenést észleltünk ( $\mathrm{p}<0,0001)$. A hsTnT átlagos szintje azonban a 3 . hónapban így is meghaladta a normális tartományt, $17 \pm 18 \mathrm{ng} / \mathrm{l}$ volt.

\section{Troponinpozitivitás a vizsgált alcsoportokban}

$\mathrm{Az}$ egyes esetek hsTnT-pozitivitását vizsgálva (melyet a vizsgálat idejében érvényes laboratóriumi referenciaértéknek megfelelően >14 ng/l-ként definiáltunk) megállapíthatjuk, hogy a beavatkozást követően 4 órával a betegek $80 \%$-ának még EFV esetében is pozitív az értéke. Ebben a csoportban a troponinpozitivitás az esetek nagy részében gyors normalizálódással járt: a 20. órában már csak 3 betegnek volt pozitív eltérése (30\%). Az AVNRT-, a PFlu- és a PF-csoportban kivétel nélkül minden betegnek pozitív volt a troponinértéke 4 órával a beavatkozás után. PFlu- és PF ablatión átesett páciensek esetében

\section{hsTnT-pozitivitás}

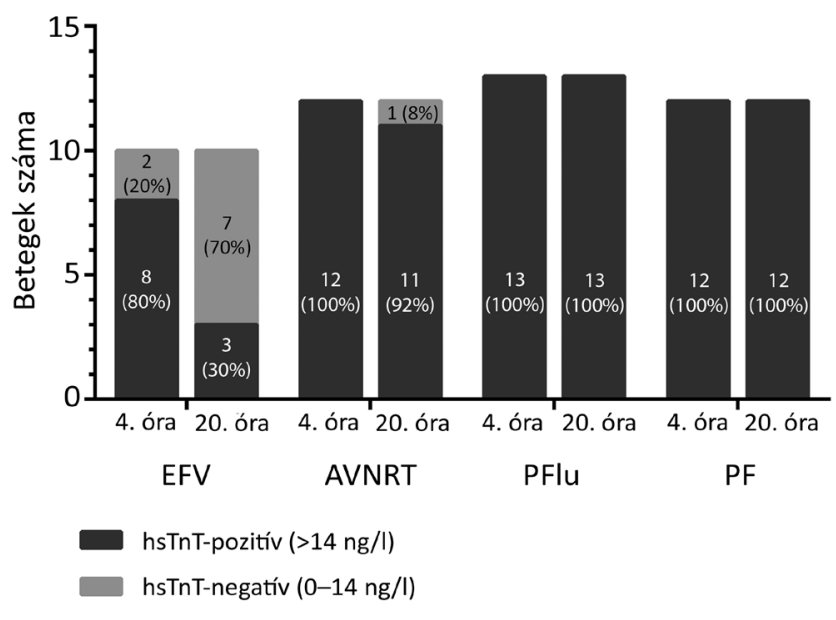

2. ábra

A hsTnT laboratóriumi pozitivitás változása a beavatkozás utáni korai időszakban beavatkozástípustól függően

AVNRT $=$ AV-csomó reentry tachycardia $; \mathrm{EFV}=$ elektrofizioló giai vizsgálat; $\mathrm{hsTnT}=$ magas érzékenységű troponin $\mathrm{T} ; \mathrm{PF}=$ pitvarfibrilláció; PFlu = pitvari flutter

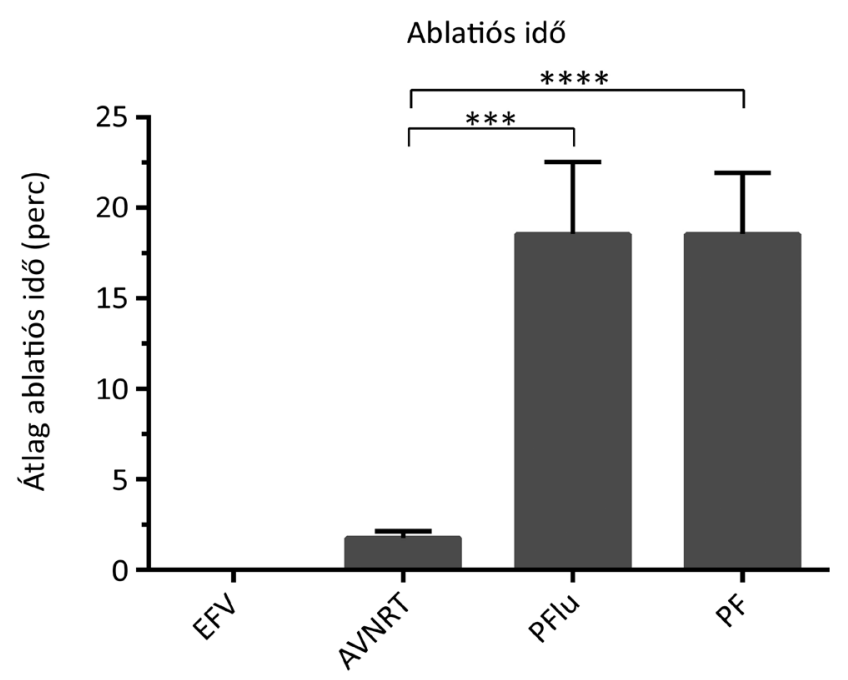

3. ábra

$$
\begin{aligned}
& \text { Ablatiós idők a beavatkozás típusa szerint } \\
& \text { AVNRT }=\mathrm{AV}-\text { csomó reentry tachycardia; } \mathrm{EFV}=\text { elektrofizioló- } \\
& \text { giai vizsgálat; } \mathrm{PF}=\text { pitvarfibrilláció; PFlu }=\text { pitvari flutter } \\
& { }^{* * *} \mathrm{p}<0,001,{ }^{* * * *} \mathrm{p}<0,0001
\end{aligned}
$$

minden betegnél perzisztált a pozitív hsTnT-szint, és még az AVNRT esetében is csak egyetlen esetben csökkent a határérték alá a troponinkoncentráció. A hsTnTpozitivitás változását az egyes csoportokban a 2 ábra mutatja be.

\section{Az ablatiós ido" és a hsTnT-szint közötti összefüggés}

Az ablatiós időkben a beavatkozások eltérő jellegét tükrözve szignifikáns különbségek mutatkoztak (3. ábra). Ablatio EFV esetében nem történt, AVNRT miatt a lassú pálya eliminálása esetén átlagosan csak $2 \pm 1$ percig alkalmaztunk RF energiát. A PFlu- és a PF-csoportban átlagosan $19 \pm 14$, illetve $17 \pm 12$ perces ablatiós idővel sikerült elérni a beavatkozás végpontját. Megvizsgáltuk, hogy összefügg-e az ablatiós idő mértéke a hsTnT-szint változásával (4. ábra). A korrelációs analízis alapján elmondható, hogy az ablatiós idő pozitívan korrelált a hsTnT közvetlen beavatkozás utáni $(\mathrm{r}=0,2958, \mathrm{p}=$ $0,0459), 4$. órás $(\mathrm{r}=0,5447, \mathrm{p}<0,0001)$ és 20 . órás értékével $(\mathrm{r}=0,5750, \mathrm{p}<0,0001)$.

\section{Megbeszélés}

Tanulmányunkban az irodalomban elérhető adatoknál részletesebben és hosszabb távon vizsgáltuk a szívizomspecifikus nekroenzimek (hsTnT és CKMB) szintváltozását a különböző típusú supraventricularis ritmuszavar miatt végzett katéterablatiós beavatkozások típusának figyelembevételével. Kimutattuk, hogy míg a hsTnT meghatározása jól reflektálja a beavatkozások hatására létrejövő szívizom-károsodást, addig a CKMB meghatározása erre nem alkalmas. Igazoltuk, hogy a hsTnT-kiáram- 

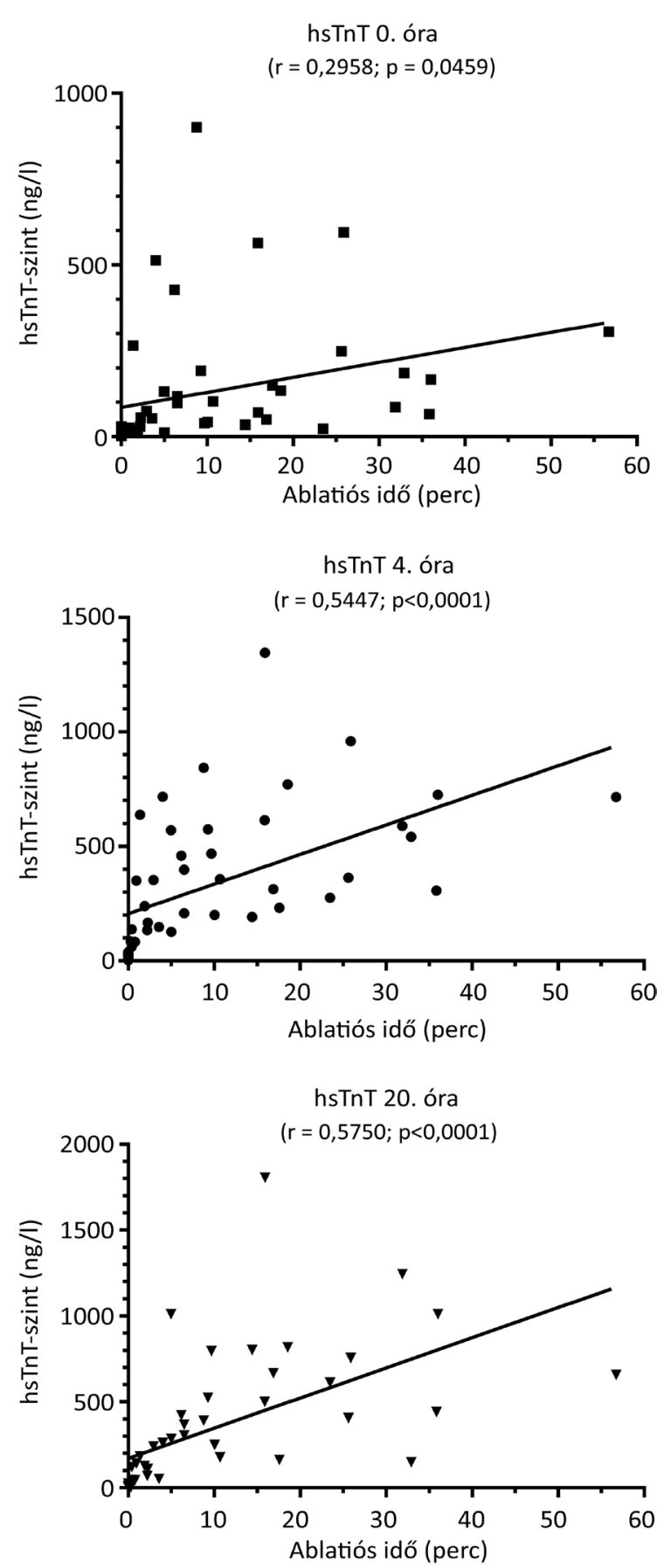

4. ábra

Összefüggés az ablatiós idő és a hsTnT-szint között a beavatkozások után közvetlenül, illetve 4 és 20 óra elteltével

hsTnT = magas érzékenységú troponin T

lás mértéke függ a beavatkozás típusától, és pozitívan korrelál a RF ablatio idejével. Vizsgálatunk eredményei alapján elmondható, hogy még az ablatióval nem járó invazív EFV után is a betegek $80 \%$-ában pozitív a biomarker szintje. A supraventricularis ritmuszavarok ablatióján átesett betegek mindegyikénél pozitív troponinértéket mértünk, a beavatkozás típusától függetlenül; a legnagyobb mértékű kiáramlás PF-ablatio után volt mérhető. Ez utóbbi megfigyelés feltehetô magyarázata az, hogy a $\mathrm{PF}$ igényel nagyobb myocardiumnecrosist okozó ablatiót.
A nekroenzimek és gyulladásos markerek elektrofiziológiai beavatkozások utáni kiáramlása ismert jelenség az irodalomban, hiszen a RF ablatio által koagulációs necrosis jön létre az adott szövetben [16]. A legelterjedtebben használt vizsgálati modell a pitvarfibrilláció-ablatio, melynek során kiterjedt ablatio történik [17, 18]. Vizsgálatunkban megerősítettük a korábbi megfigyeléseket, miszerint a CKMB nem alkalmas az ablatiót követô szívizomnecrosis megfigyelésére, szemben a hsTnT-vel. Ezt a jelenséget Haines és mtsai a RF energia által leadott magas hő CKMB-t inaktiváló következményének tekintik, ennek következtében a CKMB szintje alábecsülheti a szívizom sérülésének mértékét [19]. A hsTnT azonban RF ablatiót követően is jól jelzi a szívizom degradációjának mértékét. Meghatározásának további előnye a CKMB-zal szemben a magasabb szenzitivitás és specificitás [20]. Emiatt az akut myocardialis infarctus diagnosztizálása kapcsán több szakmai társaság és irányelv is egyedül a hsTnT-szint meghatározását javasolja, a CKMB- és mioglobinszintek rutinszerú mérésének elhagyása mellett [21]. Továbbá ismert, hogy a hsTnT nemcsak a diagnózisban, hanem a myocardialis infarctus esetén a hosszú távú utánkövetésben és prognózist illetően is jobb markernek bizonyult [22]. Ehhez hasonlóan, irodalmi adatok felvetették a hsTnT prognosztikai szerepét a PF-ablatio sikerességének előrejelzésében [23].

A troponinkiáramlás vizsgálatának jelentősége túlmutat az akut myocardialis infarctus diagnózisán és prognózisának megítélésén, széles körben vizsgálják annak mértékét különböző beavatkozások, betegségek kapcsán is. Egy amerikai összefoglaló tanulmány elektromos cardioversiót $(\mathrm{CV})$, implantálható kardioverter-defibrillátor (ICD) beültetését, illetve különböző indikációval végzett RF ablatiót követően gyújiötte össze a troponinváltozások eredményeit [24]. Míg CV-nál nem észleltek szignifikáns troponinemelkedést, beültetést követően a betegek 16\%-ában észleltek 1,5 ng/l feletti troponinértéket, valamint RF ablatiót követően is a betegek több mint 25\%-ában találtak szignifikáns emelkedést (átlagos TnT 0,2-2,4l ng/l, maximum 9 ng/l). Nagyobb emelkedést írtak le kamrai, illetve kiterjedt ablatiót (PFlu, PF, kamrai tachycardia) követően, a pitvari, valamint fokálisan leadott applikációkhoz (AVRT, AVNRT, kiáramlásipálya-eredetú kamrai extraszisztolé) képest. Mindemellett elektrofiziológiai vizsgálat esetén nem tapasztaltak jelentős TnT-kiáramlást. Ez a tanulmány összhangban van vizsgálati eredményeinkkel, miszerint kiterjedtebb laesio, illetve hosszabb ablatiós idő esetén magasabb troponinértéket kapunk. Fontosnak tartjuk megemlíteni, hogy a tanulmány a troponinizomerek közül nem a hsTnT mértékét vizsgálta, hanem a kevésbé szenzitív és specifikus szívizom-specifikus troponin T-t és I-t. Ezáltal jelen vizsgálatunk nemcsak megerősítette, hanem kiterjesztette a korábbi irodalmi adatokat.

A RF ablatio során történő gyulladást jellemző fehérjék vagy nekroenzimek változásait a leggyakrabban PF-ablatio kapcsán kutatják [23]. Kevés olyan vizsgálat létezik, 
mely a pitvarfibrilláción kívül egyéb supraventricularis ritmuszavar ablatiója kapcsán hasonlítja össze a gyulladásos markerek és a cardialis nekroenzimek kiáramlásának mértékét, ami szintén alátámasztja kutatásunk célkitűzésének jelentőségét. Brueckmann és mtsai összesen 11 beteg vonatkozásában írták le fơként gyulladásra specifikus fehérjék (interleukin-6, mioglobin, mátrixmetalloproteáz-9, illetve troponin I) szintjének emelkedését AVNRT, WolfParkinson-White-szindróma (WPW) és PFlu ablatiója során [7], amelyek közül a mátrixmetalloproteáz-9 minden beavatkozás esetén, a 120. napon is pozitív eltérést mutatott. Bednarek munkacsoportja a troponin I és a mioglobin mellett a CK, a CKMB és az aminotranszferázok szintjét is vizsgálta WPW-, AVNRT-, PFlu- és PFablatio kapcsán. Közleményükben a troponin I és a mioglobin az ablatio során leadott energiával mutatott összefüggést [12]. Ehhez hasonlóan egy holland publikációban magasabb ablatiós energia alkalmazásakor a vizsgált markerek közül leginkább a szívizom-specifikus troponin (TnT) koncentrációja emelkedett WPW-, AVNRT- és PFlu-ablatiós beavatkozás során is, $\mathrm{CKMB}$-zal és humán szívizom-specifikus zsírsav fehérjével szemben [10].

Mindkét utóbbi vizsgálat rövid távon vizsgálta a koncentrációváltozásokat, 20 órával, illetve 24 órával a beavatkozást követően határozták meg az utolsó értéket. Emiatt a laesio létrehozása és hegesedése által okozott biomarkerkiáramlás teljes időbeli változása limitált az idézett tanulmányokban. Jelen vizsgálatunkban kimutattuk, hogy a hsTnT koncentrációja minden egyes beavatkozás után megemelkedett, továbbá a referenciaértéket meghaladó pozitív ( $14 \mathrm{ng} / \mathrm{l}$ feletti) érték a 20. órában még szinte minden, ablatión átesett betegnél perzisztált. Ezzel szemben a kontroll-EFV-csoportban a 20. órában csak a betegek egyharmadában mértünk magas hsTnT-értéket. A 3. hónapos kontrollvérvételen az EFV-csoportban egyedül egy, AVNRT esetén azonban egy betegnek sem volt $14 \mathrm{ng} / \mathrm{l}$ feletti hsTnT-koncentrációja, míg a PFlu- és a PF ablatiós csoportban sorrendben négy, illetve öt egyénnek is pozitív hsTnT-szintet mértünk.

Mivel a korábban leírtak alapján az átlagos és a csúcshsTnT-koncentrációk is magasabb értéket mutattak PF és PFlu esetén, megvizsgáltuk, hogy összefügg-e a hsTnT értéke az ablatiós idő hosszával, mely feltételezhetően reflektálja az ablatiós laesiók kiterjedését. A korrelációs analízis során szignifikáns pozitív összefüggést találtunk a hsTnT-szintek és az ablatiós idő között a beavatkozás után, illetve 4 és 20 órát követően. Ez összhangban van Vasatova és mtsai megfigyelésével, miszerint a hsTnT-koncentráció az ablatiót követő 24 . órában szignifikánsan magasabb volt hosszabb ablatiós idő és magasabb applikációszám esetén [11]. Ezzel szemben egy svájci kutatócsoport nem talált összefüggést a TnTés a CKMB-koncentrációk és az ablatiós idő, illetve a leadott energia mennyisége között sem [25]. A viszonylag alacsony számú, ellentmondó szakirodalomi adatokat kiegészítve eredményeinkkel igazoltuk, hogy RF ablatio során szignifikánsan jelentősebb nekroenzimemelkedés észlelhető az elektrofiziológiai vizsgálaton átesett kontrollcsoporthoz képest, és a kiáramlás mértéke összefügg az ablatio kiterjedtségével.

Vizsgálatunk legfőbb mindennapi klinikai jelentősége az a megfigyelés, melynek alapján elmondható, hogy ha RF ablatiót követően hsTnT-szintet határozunk meg, akkor ez még a legkisebb mértékü ablatio esetén is laboratóriumi pozitivitáshoz vezet, sőt az ablatio nélküli EFV-esetek $80 \%$-ában is hasonló a helyzet. Ez jelentős differenciáldiagnosztikai problémát vethet fel, melyet tovább árnyal az a tény, hogy az ablatión átesett betegek nagy része mellkasi diszkomfortról számol be az ablatiót követően, mely a beavatkozás velejárója. Ezenfelül nem ritka, hogy a ritmuszavarok katéteres kezelését és a ritmus normalizálódását követően másodlagos ST-szakaszeltérések rögzíthetők a felszíni EKG-n (ennek gyakori oka a T-hullám-memória jelensége). Ez az triász (mellkasi panasz, EKG-eltérés és biomarkerpozitivitás) hamisan akut coronariaszindróma diagnózisához vezethet [26]. Így ezáltal felesleges invazív vizsgálatok kivitelezésére kerülhet sor a postablatiós szakban. Ennek kivédése céljából, posztoperatív mellkasi fájdalom esetén - a klinikai kép folyamatos monitorozása mellett - noninvazív kardiológiai vizsgálómódszerek (echokardiográfia, coronariaCT stb.) alkalmazása javasolható.

\section{Következtetés}

Prospektív, obszervációs vizsgálatunkban szívizom-specifikus nekroenzimek (hsTnT és CKMB) EFV, illetve AVNRT, PFlu és PF katéteres ablatiója során történt középtávú változásait hasonlítottuk össze. A hsTnT-koncentráció szignifikánsan változott EFV- és RF ablatio után, a CKMB a jelenség leírására nem volt alkalmas. A hsTnT-kiáramlás mértékét meghatározta a beavatkozás típusa, és az átlagos hsTnT-szint pozitív korrelációt mutatott az ablatio idejével. A legmagasabb hsTnT-átlagkoncentráció PF-ablatio után volt tapasztalható, mely 3 hónappal az ablatiót követóen is pozitív maradt a betegek felében. A fentiekben leírt megfigyelések jelentősen hozzájárulhatnak a RF ablatio utáni hsTnT-szint megfelelő értelmezéséhez.

\section{Limitációk}

Tanulmányunk legfóbb limitációja az alacsony betegszám, azonban a bevont betegszám összhangban van az irodalomban közölt tanulmányokban szereplő populációkkal. Az ablatio által létrejött laesio méretére - jelenleg validált módszer hiányában - indirekt módon következtettünk az ablatio idejének mérésével. Ekkor nem vettük figyelembe az applikációk során leadott összenergiát, és nem tettünk különbséget a különböző katéterek között. Eredményeink klinikai vonatkozása a téma jelentőségére való figyelem felkeltését szolgálja, megerősítésére többcentrumú, nagyobb betegszámú, randomizált klinikai vizsgálatokra lenne szükség a jövőben. 
Anyagi támogatás: A kutatómunkát a Nemzeti Kutatási, Fejlesztési és Innovációs Hivatal (OTKA K 105555) és az MTA Bolyai János Kutatási Ösztöndíj (G. L., Sz. G.) támogatta.

Szerzôi munkamegosztás: T. T., Sz. G.: A hipotézisek és a vizsgálati protokoll kidolgozása. T. T., H. Sz., Sz. G.: Statisztikai elemzés, a kézirat megszövegezése. A vizsgálatok lefolytatásában valamennyi szerző részt vett. A cikk végleges változatát minden szerző elolvasta és jóváhagyta.

Érdekeltségek: A szerzőknek nincsenek érdekeltségeik.

\section{Irodalom}

[1] Kirchhof P, Benussi S, Kotecha D, et al. 2016 ESC Guidelines for the management of atrial fibrillation developed in collaboration with EACTS. Eur Heart J. 2016; 37: 2893-2962.

[2] Kugler S, Duray G, Préda I. Novel mechanisms in the initiation and maintenance of atrial fibrillation: tailored individual treatment. [Új felismerések a pitvarfibrilláció genezisében és fenntartásában: az egyénre szabott kezelés lehetőségei.] Orv Hetil. 2018; 159: 1135-1145. [Hungarian]

[3] Végh EM, Széplaki G, Szilágyi S, et al. Electroanatomical mapping and radiofrequency ablation of tachycardia originating in pulmonary vein in an adult patient. [Fiatalkori vena pulmonalis tachycardia ablatiója elektroanatómiai térképezés segítségével.] Orv Hetil. 201 1; 152: 1374-1378. [Hungarian]

[4] Murgatroyd F, Krahn AD, Klein GJ, et al. Handbook of cardiac electrophysiology: a practical guide to invasive EP studies and catheter ablation. ReMedica, London, 2003.

[5] Schmitt C, Deisenhofer I, Zrenner B. Catheter ablation of cardiac arrhythmias. 1st edn. Steinkopff-Verlag, Darmstadt, 2006.

[6] Jaffe AS, Ordonez-Llanos J. High-sensitivity cardiac troponin: from theory to clinical practice. Rev Esp Cardiol (Engl Ed). 2013; 66: 687-691.

[7] Brueckmann M, Wolpert C, Bertsch T, et al. Markers of myocardial damage, tissue healing, and inflammation after radiofrequen cy catheter ablation of atrial tachyarrhythmias. J Cardiovasc Electrophysiol. 2004; 15: 686-691.

[8] McCarthy CP, Yousuf O, Alonso A, et al. High-sensitivity troponin as a biomarker in heart rhythm disease. Am J Cardiol. 2017; 119: 1407-1413

[9] Hernández-Romero D, Marín F, Roldan V, et al. Comparative determination and monitoring of biomarkers of necrosis and myocardial remodeling between radiofrequency ablation and cryoablation. Pacing Clin Electrophysiol. 2013; 36: 31-36.

[10] Hirose H, Kato K, Suzuki O, et al. Diagnostic accuracy of cardiac markers for myocardial damage after radiofrequency catheter ablation. J Interv Card Electrophysiol. 2006; 16: 169-174

[11] Vasatova M, Pudil R, Tichy M, et al. High-sensitivity troponin T as a marker of myocardial injury after radiofrequency catheter ablation. Ann Clin Biochem. 2011; 48: 38-40.

[12] Bednarek J, Tomala I, Majewski J, et al. Biochemical markers of myocardial damage after radiofrequency ablation. Kardiol Pol. 2004; 60: 335-341.

[13] Blomstrom-Lundqvist C, Scheinman MM, Aliot EM, et al ACC/AHA/ESC guidelines for the management of patients with supraventricular arrhythmias - executive summary: a report of the American College of Cardiology/American Heart Association Task Force on Practice Guidelines and the European So- ciety of Cardiology Committee for Practice Guidelines (Writing Committee to Develop Guidelines for the Management of Patients With Supraventricular Arrhythmias). Developed in collaboration with NASPE-Heart Rhythm Society. J Am Coll Cardiol. 2003; 42: 1493-1531.

[14] European Heart Rhythm Association, European Association for Cardio-Thoracic Surgery, Camm AJ, Kirchhof P, Lip GY, et al. Guidelines for the management of atrial fibrillation: the Task Force for the Management of Atrial Fibrillation of the European Society of Cardiology (ESC). Eur Heart J. 2010; 31: 23692429.

[15] Task Force for the Diagnosis and Management of Syncope of European Society of Cardiology (ESC), European Heart Rhythym Association, Heart Failure Association, Heart Rhythym Society, Moya A, Sutton R, Ammirati F, et al. Guidelines for the diagnosis and management of syncope (version 2009). Eur Heart J. 2009; 30: 2631-2671.

[16] Nath S, Redick JA, Whayne JG, et al. Ultrastructural observations in the myocardium beyond the region of acute coagulation necrosis following radiofrequency catheter ablation. J Cardiovasc Electrophysiol. 1994; 5: 838-845.

[17] Kornej J, Reinhardt C, Kosiuk J, et al. Response of high-sensitive C-reactive protein to catheter ablation of atrial fibrillation and its relation with rhythm outcome. PLoS ONE 2012; 7: e44165.

[18] Lim HS, Schultz C, Dang J, et al. Time course of inflammation, myocardial injury, and prothrombotic response after radiofrequency catheter ablation for atrial fibrillation. Circ Arrhythm Electrophysiol. 2014; 7: 83-89.

[19] Haines DE, Whayne JG, Walker J, et al. The effect of radiofrequency catheter ablation on myocardial creatine kinase activity. J Cardiovasc Electrophysiol. 1995; 6: 79-88.

[20] Athamneh H, Basnawi A, Siler-Fisher A. CKMB and acute myocardial infarction in the emergency department. J Emerg Med. 2013; 45: 617-618.

[21] Trost J, Feldman L. Creatine kinase-myocardial band for chest pain and suspected acute coronary syndrome. J Hosp Med. 2015; 10: 827-829.

[22] Tiwari RP, Jain A, Khan Z, et al. Cardiac troponins I and T: molecular markers for early diagnosis, prognosis, and accurate triaging of patients with acute myocardial infarction. Mol Diagn Ther. 2012; 16: 371-381.

[23] Yoshida K, Yui Y, Kimata A, et al. Troponin elevation after radiofrequency catheter ablation of atrial fibrillation: relevance to $\mathrm{AF}$ substrate, procedural outcomes, and reverse structural remodeling. Heart Rhythm 2014; 11: 1336-1342.

[24] Alaiti MA, Maroo A, Edel TB. Troponin levels after cardiac electrophysiology procedures: review of the literature. Pacing Clin Electrophysiol. 2009; 32: 800-810.

[25] Shyu KG, Lin JL, Chen JJ, et al. Use of cardiac troponin T, creatine kinase and its isoform to monitor myocardial injury during radiofrequency ablation for supraventricular tachycardia. Cardiology 1996; 87: 392-395.

[26] Jánosi A, Ofner P, Al-Maktari F, et al. Patient care of patients with myocardial infarction in Hungary. Analysis of National Myocardial Infarction Registry data collecting in 2015. [A szívinfarktus miatt kezelt betegek ellátása Magyarországon. A Nemzeti Szívinfarktus Regiszter 2015. évi adatainak elemzése.] Orv Hetil. 2017; 158: 90-93. [Hungarian]

(Széplaki Gábor dr., Budapest, Városmajor u. 68., 1122 e-mail: szeplaki.gabor@gmail.com)

A cikk a Creative Commons Attribution 4.0 International License (https://creativecommons.org/licenses/by/4.0/) feltételei szerint publikált Open Access közlemény, melynek szellemében a cikk bármilyen médiumban szabadon felhasználható, megosztható és újraközölhetö, feltéve, hogy az eredeti szerző és a közlés helye, illetve a CC License linkje és az esetlegesen végrehajtott módositások feltüntetésre kerülnek. (SID_1) 